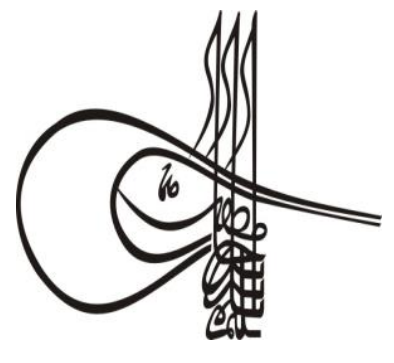

Received/Geliş: 06.08.2019
Uurktsh Studíts

Volume 14 Issue 7, 2019, p. 3919-3938

DOI: 10.29228/TurkishStudies.30156

ISSN: 1308-2140

Skopje/MACEDONIA-Ankara/TURKEY

Research Article / Araşttrma Makalesi

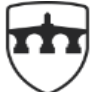

INTERNATIONAL BALKAN UNIVERSITY

EXCELLENCE FOR THE FUTURE IBU.EDU.MK

Article Info/Makale Bilgisi

Go Report Dates/Rapor Tarihleri: Referee 1 (01.12.2019)-Referee 2 (02.12.2019)

This article was checked by iThenticate.

\title{
DÜNDEN BUGÜNE BALKANLARDA BİR BAŞKENT: EDİRNE VE EDİRNE'DE YAŞAM
}

\author{
Sabri Can SANNAV
}

\begin{abstract}
öz
Edirne'nin, Orta Asya kökenli bir kavim olan Trakların göç ederek yerleşmeleri sonucunda kurulduğu bilinmektedir. Ancak daha sonra, Makedonya Kralı Büyük İskender döneminde Roma İmparatoru olan Hadrianus tarafından şehir adeta tekrar kurulmuş ve yeniden inşa edilmisstir. Bu imparatorun adına izafeten de Hadrianapolis olarak anılır olmuştur. Şehir bir ara Bulgarların hakimiyetine girmiş ve 1361 yılında I. Murat döneminde Lala Şahin Paşa kuvvetleri tarafindan ele geçirilinceye kadar Doğu Roma İmparatorluğunun hakimiyetinde kalmıştır. 1453 yılında gerçekleşecek olan İstanbul'un fethine kadar geçen 92 yıl boyunca Osmanlı Devleti'nin başkenti olan şehir, sonraki dönemde "Paşa Sancağı" ismi ile Rumeli Beylerbeyliği'ne tabi bir vilayet haline gelmiştir. Edirne XII yy.'a gelindiğinde Avrupa'nın en büyük ve önemli beşinci şehri olmuş ve adeta İmparatorluğun üniversite kenti olarak bilinir olmuştur. Edirne pek çok siyasî ve askerî olaylara tanık olduğu gibi aynı zamanda tarihi boyunca önemli kültür olaylarının da çokça yaşandığ bir şehir olmuştur. Mesela İmparatorlukta meydana gelen Mimarî yenilikler bu kentin gösterişli eserleri ile birlikte gelmiş; yine süsleme ve hat sanatının en güzel ve önemli örnekleri Edirne'de ortaya konulmuş, medreselerinde oldukça yoğun ilmî münakaşalar yaşanmış, tıp literatürüne geçen ilk deneysel uygulamalar bu şehirde yaşanmıștır. Esas kimliğini Osmanlı yüzyıllarında bulan ve devletin İstanbul'un fethinden sonra ikinci önemli şehri olan Edirne, tarih boyunca kültürel mirasımızın en çok hissedildiği gerçek bir Osmanlı şehri olmuştur. Kimliğini asıl Osmanlı döneminde bulan ve imparatorluğun ikinci kenti olan Edirne, tarih boyunca Sultan II. Murat dönemi Edirne'nin gelişimi açısından en verimli yıllar olmuştur. Bu dönemde şehir, hızlı bir gelişim göstermiştir. 1424 ve 1439 yılları arasındaki dönemde Edirne, pek çok yabancı elçi, heyet ve hükümdar tarafından ziyaret edilmiştir. Bu dönemde hamam, cami, medrese, köprü ve imaret gibi pek çok eser inşa edilmiştir. Ayrıca bu dönemde Edirne, Şehzade düğünlerine de sahne
\end{abstract}


olmuştur (hükümdarın çocukları şehzade Mehmet ve şehzade Alaaddin için görkemli sünnet düğünleri yapılmıștır). Ayrıca Tunca Nehri boyunda ikinci bir sarayın yapımına da bu dönemde başlanmıștır. II. Murat, Edirne'yi bir askeri üs olarak değerlendirmiş ve pek çok seferi Edirne'den yönetmiştir.

İstanbul fethedildikten sonra her ne kadar hükümetin merkezi buraya taşınsa da Edirne, Osmanlı Devleti'nin fikrî başkenti olmaya devam etmiş ve önemini bir süre daha korumuştur. Nitekim II. Mehmet de İstanbul'un fethinden sonra Edirne'yi bırakmamış ve sıklıkla buraya gelmiştir. Babasının Edirne Sarayı içinde inşa ettirdiği sarayı daha da genişletip, güzelleştirmiştir. Yine o dönemde Hacı Alemüddin Medresesi, Zağnos Paşa ve Ayşekadın Camileri inşa edilmiştir.a kültürel mirasımızın en yoğun olarak hissedildiği bir şehir olmusstur.

Anahtar Kelimeler: Edirne, Lala Şahin Paşa, Selimiye Camii

\title{
A CAPITAL IN THE BALKANS FROM PAST TO PRESENT: LIFE IN EDIRNE AND EDIRNE
}

\begin{abstract}
It is known that Edirne was founded by the Thracians who migrated from Central Asia in the early ages and settled there. Afterwards, the city was reconstructed as if it had been rebuilt by Hadrian, one of the Roman Emperors during the reign of Alexander the Great, and was named as Hadrianopolis. Some time under Bulgarian rule and remained under Byzantine rule until it was conquered by Lala Shahin Pasha in 1361 during the reign of Murat I. The city, which was the capital of the Ottoman Empire for 92 years until the conquest of Istanbul in 1453, remained a province with the name of "Pasha Sanjak" depends on Grand Seignior Rumeli in the later years. Known as the university city of the Empire, it became the fifth largest city in Europe in the XII century. Edirne has been a city of intense cultural events throughout history. Architectural innovations came from the structures of this city; The best examples of calligraphy and decorative arts are given here, many madrasas witnessed intense discussions, and the first applications in the history of medicine began here. Edirne which has been the second city of the empire, found its identity during the Ottoman period and has been the city where our cultural heritage has been felt most intensively throughout history. The period of Sultan Murat II was one of the most productive years for the development of Edirne. During this period, the city developed rapidly. During the period between 1424 and 1439, Edirne was visited by many foreign ambassadors, delegations and monarchs. During this period, many works such as baths, mosques, madrasas, bridges and imaret were built. Also during this period, Edirne, became the scene of the Prince's weddings (the ruler's children prince Mehmet and prince Alaaddin grand circumcision ceremonies were held). Also, the construction of a second palace along the Tunca River began in this period. Murat II considered Edirne as a military base and led many expeditions from Edirne. Although the center of the government moved there after the conquest of Istanbul, Edirne continued to be considered as the capital of the Ottoman
\end{abstract}


Empire and maintained its importance for a while. As a matter of fact, Mehmet II did not desist Edirne after the conquest of Istanbul and came here often. The palace built by his father in Edirne Palace was further expanded and turned into a very beautiful sight. In that period, Hac1 Alemüddin Madrasa, Zagnos Pasha and Ayşekadın Mosques were built.

\section{STRUCTURED ABSTRACT}

It is known that Edirne was founded by the Thracians who migrated from Central Asia in the early ages and settled there. It was later rebuilt by the Roman emperor Hadrianus during the reign of Alexander the Great in which in its name it was referred to as Hadrianopolis. Once it was under the bulgarian rule and remained under Byzantine rule until it was conquered by Lala Şahin Pasha in 1361 during the reign of Murat I. The city, which was the capital of the Ottoman Empire for 92 years until the conquest of Istanbul in 1453, in the following years became a province under the name of "Paşa Sancak" that was connected to Rumelian Governors. Known as the university city of the Empire in the XII century, it became the fifth largest city in Europe.

During history, Edirne has been a Balkan city where political and military events as well as cultural activities were intense. Many innovations of Ottoman architecture came into the structures of this city; the most beautiful examples of calligraphy and decorative art were given here, many madrasas witnessed intense discussions and here were made the first applications in the history of medicine. It can be said that Edirne, which found it's identity during the Ottoman period and was the second city of the empire, has been the city where our cultural heritage was felt most intensively throughout history.

In the studies on the history of Edirne, Rifat Osman's Edirne Rehnüm and Osman Nuri Peremeci's Edirne History are very important in terms of forming the first steps. Although some important studies have been made about Edirne in the following years, it is difficult to say that these are sufficient studies in terms of the mission undertaken by the city during history. In this study, we approached the history of Edirne in a chronological integrity and reiterated the importance of this city in the Balkans.

The issue of when and how the conquest of Edirne happened, has been lately discussed by Bulgarian historian A. Burmov and İsmail Hakk1 Uzunçarş1l1. According to Burmov, Edirne must have been conquered immediately after the Battle of Çirmen (26 September 1371), in late September or in early October of 1371. While İsmail Hakkı Uzunçarş11 gives the date of the conquest of Edirne as 1364 or 1365. When Edirne was conquered, Murat I left Lala Şahin Paşa in Edirne and he went to Dimetoka to form a headquarter there. Murat I built a mosque and a small palace in Dimetoka; before settling in Edirne, Lala Şahin Pasha went across Meriç with his forces in order to secure the city completely from the northern front and when it came to Filibe besieged the city immediately. After the commander of the city handed over the city, he went to Serbia with his family. After Lala Şahin Paşa possessed Filibe, he fortified the city and built a stone bridge over the river. The conquest of Filibe is important in terms of both the conquest of Edirne and the conquest of Rumelia and the persistence of these conquests. The 
acquisition of Filibe meant that the Bulgarian and Byzantine, and even the Serbs in Macedonia, had no contact with each other. Furthermore, the economic value of Filibe at that time was extremely important. Rice growing region of Bulgaria was formed by this environment. When the Turks conquered Filibe, they acquired this wealth too.

After the conquest of Edirne, the name of the city which was called "Hadrianopal" until then, it was changed by Murat I as Edrine (Edirne since the 18th century). A church located inside the castle was transformed into a mosque (Church Mosque), another church was transformed into a mosque under the name of "Halebiye". Murat I, who liked the location of Edirne, ordered the construction of palaces here. Although there was a Tekfur palace in Kaleiçi at that time, it was not seen as a place to admire or live in. This palace was located northeast of the castle. Murat I lived in Dimetoka until the palace in Edirne was built. However, the exact location of the first palace in Edirne is not known. Although it is known that Yildırım Bayezid had built a palace on the site of the Selimiye Mosque, it is not clear whether it was built after burning the palace that Murat I built, or if it was built as some historians have written after a fire. When the construction of the Edirne Palace was completed in 1367, Murat I moved the central government from Dimetoka to Edirne.

One of the important rulers of the Ottoman Empire Murat II died in 1451 and Mehmet II succeeded to the throne. When Mehmet II succeeded to the throne for the second time and this time, his target was Istanbul, the Byzantine capital which had lost its power. When he first came to the throne the sovereign who had made the necessary planning for the siege with the efforts of the people around him; he saw such a conquest as the guarantee of the future of the state and the basis of the universal politics he wanted to establish. On the other hand, it was important to conquer the region because of its geopolitical position in the middle of Rumelia and Anatolian geography that prevented contact. In addition to his geographical and political imperative, it was necessary to have figured out that such a conquest would arouse spiritual interest.

Mehmet II began preparations for the siege in Edirne. As a matter of fact, first of all, he improved Edirne's arsenal and expanded it. Operating the iron mines in the Istrranca Mountains, now called Demirköy and Samakof in the south of Sofia, he brought the iron extracted from these places to Edirne and with the most valuable craftsmen that he brought here, poured magnificent balls that were not made anywhere in the world until that date.

In the spring of 1453 , he moved with a large and strong army from Edirne to Istanbul and took the city under siege for 51 days from sea and land. Istanbul, which has been besieged many times until that date, was taken over in May 29, 1453 by Mehmet II thus ending the so-called Middle Ages and started a new era in history.

Although the center of the government moved there after the conquest of Istanbul, Edirne continued to be the capital of the Ottoman Empire on an intellectual basis and maintained its importance for a while. As a matter of fact, Mehmet II even after the conquest of Istanbul didn't desist Edirne and came here from time to time. The palace built by his father in Edirne Palace was further expanded and became beautiful. 
Also in that period Hac1 Alemüddin Madrasa, Zağnos Pasha and Ayşekadın Mosques were built.

About the history of Edirne, even though Edirne was the capital city of the Ottoman Empire for many years and despite it's importance, it is not a very studied area. In this study, we tried to evaluate the general history of Edirne in the Ottoman Empire in a panoramic perspective. For this, we have benefited from the Ottoman archive and books and articles written to this day. Of course, since we have been working on this study for a very long period of time, we have benefited from the works that have brought more attention to this field rather than many resources. Thus, we wanted to remind again the city of Edirne to the academy world. In the meantime, we noticed that there is not much resources and studies about Edirne. We have once again demonstrated the necessity of addressing the history of Edirne over the centuries in an academic way.

Regarding the history of Edirne, the works of important writers such as Osman Peremeci, Ahmed Badi Efendi and Abdurrahman Hibri are extremely important. However, these works were written many years ago. Therefore, new studies should be made under the light of these works and Edirne should be studied in great detail not only historically but also culturally and socially.

Keywords: Edirne, Lala Shahin Pasha, Selimiye Mosque

\subsection{Edirne'nin Fethi}

Edirne'nin Türkler tarafından hangi zamanda ve hangi şartlarda fethedildiği meselesi, son defa Bulgar tarihçisi A. Burmov ve İsmail Hakkı Uzunçarşılı tarafından ele alınmıştır. Edirne, Burmov'un iddiasına göre Çirmen Savaşından (26 Eylül 1371) çok kısa bir süre sonra, 1371 yılının Eylül ayı sonu ya da Ekim ayı başlarında fethedimiştir. İsmail Hakkı Uzunçarşılı ise Edirne'nin fethi tarihini 1364 veya 1365 olarak vermektedir.(İnalcık, 1988: 148; Uzunçarş1lı, 1988: 148).

Türkler, XIV. yüzyılın ortalarından itibaren Balkan yarımadasına geçmeye başlarlar. O tarihlere kadar birbirleri ile mücadele eden Balkanlı devletler Osmanlılara karşı birlik olup Türk akınlarını durdurmaya çalışmışlarsa da başarılı olamazlar. I. Murat 1362 yılında ordusu ile beraber Balkan yarımadasına geçer ve Keşan, Çorlu, Lüleburgaz, Dimetoka ve Babaeski'yi fetheder ve sonrasında da Lala Şahin Paşa'yı Edirne üzerine gönderir. Lala Şahin Paşa, önce Sazlıdere mevkiinde Türklere karşı birleşmiş olan Bulgar ve Bizans kuvvetlerini kesin bir yenilgiye uğratır. Bu gelişme üzerine Edirne Tekfuru olan Adrian kuvvetlerinin bir kısmı ile Meriç Nehri boyunca Enez'e kadar kaçmaya, buradan da Sırbistan'a ulaşmaya muvaffak olur. Tekfurlarının kaçtığını gören Edirne halkı hiçbir taraftan yardım alamayacağını anlayınca şehrin kapılarını Türk ordusuna açmak mecburiyetinde kalırlar.(Sertoğlu, 2010:101) Türklerin Edirne Kalesi'ni muhasara altına aldıklarında şehir dışındaki Rum bağ ve bahçelerinden yedikleri yemiş ve üzümlerin paralarını ağaç ve kütüklerin diplerine bırakacak kadar başkalarının haklarına saygılı olduklarına dair bir takım rivayetler de dilden dile dolaşır.

Edirne fethedilince I. Murat, Lala Şahin Paşa'yı Edirne'de bırakmış ve kendisi de Dimetoka'ya giderek burada bir karargah oluşturmuştur. I. Murat Dimetoka'da bir camii ve bir de küçük bir saray inşa ettirmiş; Lala Şahin Paşa ise Edirne'de yerleşmeden önce şehri Kuzey cephesinden tamamıyla emniyete alabilmek için kuvvetleriyle Meriç boyunca ilerlemiş ve Filibe önlerine gelince şehri hemen kuşatmıştır. Şehrin kumandanı şehri teslim ettikten sonra kendisi de ailesi ile Sırbistan'a gitmiştir. Lala Şahin Paşa Filibe'ye sahip olduktan sonra şehri tahkim etmiş ve nehir üzerine de taştan bir köprü inşa ettirmiştir. Filibe'nin ele geçirilmesi gerek Edirne, gerekse de 
Rumeli'nin fethi ve söz konusu fetihlerin kalıcılığını sağlayabilmesi bakımından önemlidir. Filibe'nin alınması, Bulgar ve Bizanslıların, hatta Makedonya'daki Sırpların birbirleri ile irtibatının kesilmesi anlamına geliyordu. Ayrıca Filibe'nin o dönemde ekonomik değeri son derece önemliydi. Bulgaristan'ın pirinç yetiştiren bölgesini bu havali oluşturmaktaydı. Türkler Filibe'yi ele geçirince bu zenginliği de elde etmiş oldular.(Sertoğlu, 2010: 101-102)

Edirne'nin alınmasından sonra şehrin o zamana kadar "Hadrianopal" olan adı I. Murat tarafından "Edrine" (XVIII. yüzyıldan itibaren Edirne) olarak değiştirilmiştir. Kale içinde bulanan bir Kilise camiye döndürülmüş (Kilise Camii), yine başka bir kilise de "Halebiye" adıyla yine Camii haline getirilmiştir. Edirne'nin yerini oldukça beğenen I. Murat, burada saraylar yapılmasını emreder. O dönemde Kaleiçi'nde bir Tekfur sarayı varsa da beğenilecek, içinde yaşanılacak bir yer olarak görülmemiştir. Bu Saray kalenin kuzeydoğusunda bulunuyordu. I. Murat Edirne'deki saray inşa edilinceye kadar Dimetoka'da ikamet etmiştir. Bununla birlikte Edirne'de ilk sarayın nerede yapıldığ 1 kesin olarak bilinmemektedir. Yıldırım Bayezid'in şimdiki Selimiye Camii yerinde bir saray yaptırdığı biliniyorsa da, bunu, I. Murat'ın yaptırdığı sarayı yıktırıp da mı, yoksa bazı tarihlerin yazdığ gibi bir yangından sonra mı yaptırdığı belli değildir.1367'de Edirne Sarayı'nın inşası bitince I. Murat hükümet merkezini Dimetoka'dan Edirne'ye taşımıştır.(Peremeci, 1939:12)

\subsection{Osmanlı Sultanları ve Edirne}

\subsubsection{Yuldırım Bayezid Dönemi (1389-1402)}

Edirne'nin Yıldırım Bayezid döneminde önemi daha da artmıştır. Bunun da en önemli sebebi Yıldırım Bayezid'in savaşlardan zaman buldukça Edirne'ye gelmesi ve Edirne Sarayında ve civarında vakit geçirmesi olsa gerektir. Örneğin Sırp Kralının kızı Evdokiya ile düğününü burada yapmış; Bizans üzerine, Avrupa'ya yapılan seferlere de burada hazırlanmayı tercih etmiştir. Kale dışındaki mahalleler onun zamanında kurulup gelişmeye başlamış ve şehir gittikçe önem kazanmıştır. Edirne'nin imarlaşmasında da onun döneminde önemli mesafeler alınmıştır. Yıldırım Mahallesi'ndeki Yıldırım Camii ile Selimiye Camii'nin yanında bulunan Saray Hamamı o zamandan kalmadır. Bununla birlikte Edirne'nin daha da büyük önem kazanması esasen şehzadelerin taht uğruna birbirleri ile mücadele ettikleri zamandan başlamaktadır. Yıldırım, Timur tarafindan Çubukova'da yenilip Anadolu Timur'un orduları tarafından çiğnenmeye başlayınca, Yıldırım'ın oğlu Süleyman, Bursa'dan saray halkının tamamını ve hazineyi Edirne Sarayı'na yerleştirmiştir. Bu nedenle Şehzadelerin kardeş kavgalarının çoğu Edirne civarında gerçekleşmiştir.(Peremeci, 1938:12-13)

\subsubsection{Mehmet (Çelebi) Dönemi (1413-1421)}

Süleyman Çelebi günümüzdeki Eski Camii'nin temellerini atmış, kardeşi Musa Çelebi bu inşaatı devam ettirdiği gibi bir de medrese ilave etmiş, Mehmet Çelebi ise külliyenin inşasını tamamlamıştır. Birbirleri ile saltanat mücadelesinde olan şehzadelerin aralarındaki kanlı muharebelere rağmen bu muazzam sayılacak kompleksi ihmal etmeyerek tamamlamaları Osmanlı idarecilerinin şehre ve şehirciliğe verdikleri önemi göstermesi bakımından son derece önemlidir. (Ayverdi, 1999: 194)

Mehmet Çelebi 1421 'de öldüğünde oğlu II. Murat Manisa'dan Edirne'ye çağrılmış ve o gelinceye kadar ölümü halktan gizlenmiştir. Naaşı tahnit edilerek Bursa'ya gönderilmiş, geriye kalanlar ise "Salhane" adı verilen mezarlığa gömülmüş ve üzerine de bir kitabe konulmuştur. Ancak söz konusu kitabe günümüze kadar ulaşmadığı için mezar yeri hakkında bilgimiz bulunmamaktadır. (Hibri,1996:393) İktidara gelen Sultan II. Murat'a karş1, öncelikle Yıldırım Bayezid'in çocuklarından Mustafa Çelebi, sonra da II. Murat'ın kardeşi Küçük Mustafa ayaklanmıştır. Bu isyanları bastıran Sultan II.Murat, 1422 yılında Edirne'ye ayak basmıştır. 


\subsubsection{Murat Dönemi (1421-1451)}

II. Murat zamanı Edirne'nin gelişimi açısından en güzel ve en verimli yıllar olmuştur. $\mathrm{Bu}$ dönemde şehir, hızlı bir gelişim göstermiştir. 1424 ve 1439 yılları arasındaki dönemde Edirne, pek çok yabancı hükümdar, elçi ve heyet tarafindan ziyaret edilmiştir. Bu dönemde hamam, cami, medrese, köprü ve imaret gibi pek çok eser inşa edilmiştir. Ayrıca bu dönemde Edirne, Şehzade düğünlerine de sahne olmuştur (hükümdarın çocukları şehzade Mehmet ve şehzade Alaaddin için görkemli sünnet dügünleri yapılmıştır). Ayrıca Tunca Nehri boyunda yeni bir sarayın yapımına da bu zamanda başlanmıştır. II. Murat, Edirne'yi askeri bir merkez olarak değerlendirmiş ve pek çok seferi Edirne' den yönetmiştir. (Usal, 2018: 43)

Günümüze kadar ulaşmış olan Muradiye Camii, Bedesten, Üçşerefeli Camii, Darülhadis Camii; Topkap1 ve Tahtakale hamamları; günümüzde yeri dahi bilinemeyen "Acemi oğlanları kışlası"; "Eski Bedesten”, günümüzde Sarayiçi olarak adlandırılan bölgedeki saray; pek çok medrese, Gazi Mihal Camii, Gazi Mihal imaret ve hamamı, köprüsü, Şah Melek Paşa Camii, Şahabettin Camii, Saruca Paşa Camii, Mezit Bey Camii, Mezit Bey hamam ve kervansarayı ile imareti bu hükümdarın döneminden günümüze ulaşan eserlerdir. Onun döneminde yapılıp da günümüze kadar ulaşmayan pek çok eser de bulunmaktadır. Edirne şehri bu devirde gerçek anlamda bir hükümet merkezi haline geldiği gibi ticaretin de çok canlı olduğu bir şehir haline gelmiştir. Öyle ki adeta dünyanın en önemli mimarları, en usta sanatkarları, en tahsilli ilim adamları, en ince hisli şairleri Edirne'de toplanmışlardır. Bu hükümdar döneminde göz alıcı kilimler, halılar, "velense" olarak adlandırılan yün battaniyeler ayrıca "boğası" adı verilen minder örtüleri, "beledi" adındaki nakışlı pamuk kumaşlar, iç çamaşırlar ve çarşaflar dokunmuştur. En güzel savaş malzemeleri, dünyanın en güzel kokan mis sabunları, en lezzetli şekerlemeleri Edirne'de yapılmaktaydı. Özellikle Edirne ve çevresinde yetiştirilen güllerden imal edilen gül yağları ve gül suları bütün pazarlarda aranan ürünlerdendi. Venedik, Dubrovnik ve Ceneviz'den gelen tüccarlar hemen hemen her gün Edirne'den kervanlar ile memleketlerine söz konusu ürünleri göndermekteydiler. Yine Edirne'nin Kervansaraylarında Hintli ve İranlı tüccarların getirdikleri mallar satılıyordu. O tarihlerde İstanbul fethedilmemiş olması nedeniyle kervanlar Gelibolu limanına giderler ve sonrasında da gemiler ile Avrupa, Misır ve oradan da Suriye'ye nakledilirlerdi. İște bu yolun üzerinde yine II. Murat tarafindan Ergene Nehri üzerine yaptırılan Uzunköprü Türk Devleti'nin gücünü göstermesi bakımından önemliydi. II. Murat burada sadece büyük ve uzun bir köprüyü yaptırmakla yetinmemiş, köprünün bir tarafina imareti ile, kervansarayı ile, medresesi ile, camii ile yeni bir kasaba (Uzunköprü Kasabas1); diğer yanına da bir köy inşa etmiştir.(Peremeci, 1939:13-14)

II. Murat, oğulları Alaaddin ve Mehmet için Edirne'de büyük sünnet merasimleri düzenlemiştir. (Nutku, 1972: 42) Edirne'de pek çok şanlı, pek sevinçli günler yaşayan II. Murat burada bir çok acılı ve kederli günlere de tanık olmuştur. Örneğin çok sevdiği oğlu Alaaddin'i genç yaşlarında burada kaybetmiş ve bu durum kendisini oldukça üzmüş, ruhsal durumunda bir takım bozulmalara sebep olmuştur. Ayrıca Macar, Leh, Eflak ve Sırp kuvvetlerinin Jan Hunyad'ın kışkırtmaları ile birleşip İzladı Derbendi'ne kadar geldiklerini, Osmanlı ordusundaki komutanların kendilerine, kuvvetlerine çok güvenmeleri ve gafletleri yüzünden yenildiğini de burada haber almıştır. (Lamartine, 2011:188)

II. Murat, Macar ve Leh kuvvetleri ile sulhu Edirne'de gerçekleştirmiş; burada Halil, Şahabeddin ve Saruca Paşa'larla Molla Hüsrev'den oluşan bir barış heyeti oluşturarak oğlu ondört yaşındaki Mehmet'i Osmanlı tahtına geçirmiş, kendisi tahttan çekilerek Şerbettar Hamza Bey'i ve İshak Paşa'y1 yanına alarak 1441'de Manisa'ya gitmiştir.(Uzunçarş111, 1988: 430-432)

\subsubsection{Mehmet Dönemi (1451-1481)}

II. Mehmet II. Murad'ın dördüncü oğlu olarak 30 Mart 1432 tarihinde Edirne' de doğmuştur. 1443 yılında lalaları Kassabzade Mahmut ve Nişancı İbrahim b. Abdullah Bey ile beraber Edirne' den 
Manisa'ya vali olarak gönderilmiştir. Bu tarihlerde Amasya valisi olan ağabeyi şehzade Alaaddin Ali Çelebi'nin ölümü üzerine tahtın tek yasal vârisi olmuştur. Tahttan feragat etmeyi düşünen II. Murat 847 (1444) baharında kendisini Manisa' dan yanına getirtmiştir. Edirne'de 12 Haziran 1444'de Sırp despotu, Macar kralı Hunyadi Yanoş'un temsilcileri ile barış koşulları görüşülürken II. Mehmet de hazır bulunmuştur. Sonrasında II. Murat oğlu Mehmet'e tahtını bırakarak Anadolu' ya geçmiş ve Yenişehir'de Karamanoğluları ile şahsı ve "Mehmet Bey" adına bir "ahidname" imzalanmıştır. Ağustos ayında ise kapıkulu ve paşalar önünde olduğu halde Mihalıç ovasında tahtı oğlu Mehmet'e bıraktığını resmen ilân etmiştir. II. Murat'ın bu olaylardan sonra Bursa civarında inzivâ hayatına çekildiği bilinmektedir. Ancak Osmanlı Devleti'nin on iki yaşında tecrübesiz bir şehzadenin ellerine teslim edilmesi içte ve dışta büyük buhranlara yol açılmasına neden olmuştur. Çıkan olaylar nedeniyle Balkanlar'da ve Anadolu'da II. Murat zamanında alınan pek çok yer terkedilmek mecburiyetinde kalınmıştır. 1440 yılında büyük ölçüde ele geçirilen Sırp despotluğu önceki sahibi olan Georg Branković’e geri verilmiş, Eflak beyinin tâbiiyet bağları Macarların aracılığı ile gevşetilmiş ve böylelikle Osmanlı Devleti etrafinda söz konusu bu beyliklerin üzerinde Macar etkisi kuvvetlenmiştir. Ayrıca Karamanoğullarına Beyşehir, Seydişehir, Akşehir, ve Oklukhisarı bırakılmıştır. Arnavutluk'ta Gin Zenebissi ayaklanması meydana gelirken eski Akçahisar subaşısı olan İskender Bey de isyana kalkışmıştır. Mora Despotu Konstantin de, Güneyde Korint'i geçerek Osmanlı bölgesine tecavüzde bulunmuştur. 1443 yılının kış aylarında düşmanla bir araya gelerek Sofya'da bulunan bir Vladikayı başlarına getiren Bulgarlar dahi başlı başına bir tehdit unsuru olarak ortaya çıkmıştır. Neticede Edirne' de oluşturulan barışa karşı Macaristan sahasında savaşçı bir akım gelişmiş ve bunun sonucunda da yeni bir Haçlı seferinin hazırlıklarına başlanmıştır.(İnalcık, 1996: 395)

Sultan Mehmet yukarıda bahsedilen tüm bu olumsuzluklar ile mücadele ederken ayrıca önemli bir iç sorunla da karşı karşıya kalmıştır. 1444 yılının Yaz aylarında İstanbul'da paşalar arasında görülen çekişme ve rekabet, Edirne'deki halkın bir kısmının korku içerisinde Anadolu'ya göç etmesi ve kanlı Hurûfî ayaklanmaları, Edirne'yi perişan eden büyük yangın bu sorunların en başlarında gelmekteydi. Genç padişah vaziyete bir türlü hakim olamamıştır. Esasında II. Murat idareyi daha çok veziri Çandarlı Halil Paşa' ya teslim etmişti. Fakat Haçlı ordusu 18-22 Eylül arasında Tuna Nehrini geçince Çandarlı ve ona taraftar olanlar II. Murad'ı tekrar tahta çıkartmayı arzu etmişler ve II. Murat'ı buna ikna etmeye muvaffak olmuşlardır. II. Murat kısa bir sürede Edirne'ye gelmiştir. Varna'da II. Murad'ın başında bulunduğu Osmanlı ordusu ile Haçlı kuvvetleri karş1 karşıya gelmiş ve Haçlılar burada ağır bir yenilgiye uğramıştır. Çandarlı Halil Paşa, II. Murat'1 gerçek padişah olarak görmüş ve onu muhaliflerine karşı Edirne'de ikameti için ikna etmeye çalışmışsa da II. Murat Edirne'de fazla zaman geçirmeyerek Manisa'ya çekilmiştir.

Yeniçerilere güvenen Çandarlı Halil Paşa, Sultan II. Murat'1 yeniden tahta geçirmek için faaliyetlerini hızlandırmıştır. (İnalcık, 1996: 395-396) Nitekim Edirne'de II. Murat ile Şehzadesinin yanında yer alan devlet adamları arasında büyük bir anlaşmazlık ve tartışma söz konusu olmuştur. Veziriazam Çandarlı Halil Paşa ve yeniçeriler Osmanlı tahtında II. Murat'ı görmek isterlerken; Zağanos, Şehâbeddin ve Saruca Paşa gibi vezirler de II. Mehmet'in yanında yer almışlardır. Çandarlı'nın barışçı politikasına karşılık muhalifleri genç hükümdarı fetihlere, özellikle de İstanbul'un fethine teşvik etmekteydiler. Bu nedenledir ki II. Murat genç hükümdara ve onun safinda yer alan devlet adamlarına ihtarlarda bulunmak mecburiyetinde kalmıştır. Halil Paşa da yeniden II. Murad'1 tahta geçirmek için bazı tedbirler almıştır. Ancak II. Mehmet'in birinci saltanatından çekilmesinin gerçek nedeni Edirne'de meydana gelen "Buçuktepe olayı"dır. Osmanlı Devleti tarihinde meydana gelen ve ilk yeniçeri ayaklanması olan bu olayın görünürdeki nedeni Osmanlı para birimi olan akçenin ayarı ile oynanarak değerinin düşürülmesidir. Uzun zamandır maaş alamayan yeniçeriler akçenin değer kaybetmesinden memnun olmamışlar ve bu nedenle de isyana kalkışmışlardır. Asiler evvela Rumeli Beylerbeyi olan Hadım Şehâbeddin Paşa'nın evini yağma 
etmişler, sonrasında da şehrin doğusunda bulunan tepelik mevkide toplanmışlardır. Söz konusu kalkışma, yeniçerilerin maaşlarına yarım (buçuk) akçe zam yapılarak yatıştırılmaya çalışılmış ve o tarihten itibaren söz konusu tepe "Buçuktepe" adı ile anılır olmuştur. İsyancılar bu şekilde sakinleştirilseler de yeniçeriler bundan böyle genç hükümdardan yüz çevirerek babasının onun yerine padişah olmasını talep etmişlerdir. Bu olaylar üzerine Çandarlı II. Murat'a gizlice haber göndermiş ve 1446 yılında II. Murat Edirne'ye gelerek tekrar Osmanlı tahtına çıkmıştır. Bu gelişme üzerine II Mehmet de yanındaki güvenilir adamları ile birlikte Manisa'ya dönmek zorunda kalmıştır.(Özcan:343-344)

II. Murat'ın ikinci padişahlığı Edirne'ye oldukça parlak günler yaşatmıştır. Sırbistan'a, Arnavutluk'a, Mora'ya önemli seferler yapılmış ve zaferler elde edilmiştir. Varna mağlubiyetinin ardından intikam almak isteyen Avrupa'da Jan Hunyad'ın komutasında Avrupa'da hazırlanan haçlı ordusu, Kosova'da 1450'de üç gün süren bir savaştan sonra tekrar yenilgiye uğratılmıştır. Bu savaş aynı zamanda Osmanlılar üzerine yapılan son haçlı savaşı olmuştur. II. Murat bu savaş sonrasında Edirne' de büyük düğünler yaparak oğlu II. Mehmet'i Maraş tarafları Beyi Dülkadiroğlu Süleyman Bey'in kızı Sitti Şah Sultan ile evlendirmiştir. (Babinger, 2003: 67-68)

II. Murat 1451 'de hayatını kaybedince Osmanlı tahtına II. Mehmet yeniden geçmiştir. II. Mehmet ikinci defa ve kesin bir şekilde tahta geçince amacı bundan böyle gücünü iyice kaybetmiş bulunan Bizans Devleti'nin başkenti İstanbul olmuştur. Henüz şehzadeliğinde ve hükümdarlığının ilk y1llarında çevresindekilerin de telkiniyle şehri kuşatmak için lüzumlu planları gerçekleştirmiş olan hükümdar; böyle bir fethi, devletin geleceğinin teminatı ve kurmak istediği evrensel siyasetin dayanağı olarak görmüştür. Ayrıca jeopolitik açıdan Rumeli ve Anadolu topraklarının göbeğinde yer alarak irtibata engel olan bir pozisyonda bulunmasi nedeniyle buranın fethedilmesi elzem bulunmaktaydı. Coğrafî ve siyasî zorunluluğun yanısıra bu fethin mânevî açıdan da etki uyandıracağı da muhakkak hesap edilmiş olmalıdır. (Emecen: 212)

II. Mehmet, Fetih hazırlıklarına Edirne' de başlamıştır. Nitekim bunun için öncelikle Edirne tophanesini genişletmiştir. Istıranca Dağları'ndaki günümüzde Demirköy olarak adlandırılan yer ile Sofya'nın güneyinde yer alan Samakof'da olan demir madenlerini işleterek, buralardan çıkarılan demirleri Edirne'ye getirtmiş ve buraya getirttiği en yetkin ustalara o tarihe kadar dünyanın hiçbir yerinde yapılmayan, görkemli toplar döktürmüştür. (Peremeci, 1939: 16)

1453 yılı İlkbaharında Edirne'den büyük bir ordu ile İstanbul üzerine yürümüș ve șehri denizden ve karadan 51 gün sürecek olan kuşatma altına almıştır. $O$ tarihe kadar defalarca kuşatılan İstanbul'u 29 Mayıs 1453'te almaya muvaffak olan II. Mehmet böylelikle Ortaçağ olarak adlandırılan dönemi sona erdirerek tarihte yeni bir dönem başlatmıştır.

İstanbul fethedildikten sonra her ne kadar hükümetin merkezi buraya taşınsa da Edirne, Osmanlı Devleti'nin fikrî başkenti olmaya devam etmiş ve önemini bir süre daha korumuştur. Nitekim II. Mehmet de İstanbul'un fethinden sonra Edirne'yi bırakmamış ve sıklıkla buraya gelmiştir. Babasının Edirne Sarayı içinde inşa ettirdiği sarayı daha da genişletip, güzelleştirmiştir. Yine o dönemde Hacı Alemüddin Medresesi, Zağnos Paşa ve Ayşekadın Camileri inşa edilmiştir.(Peremeci, 1939:17)

\subsubsection{Bayezid Dönemi (1481-1512)}

II. Mehmet'in Gülbahar Hatun'dan dünyaya gelen büyük oğlu II. Bayezid, 1448'de Dimetoka'da dünyaya gelmiştir. Şehzade, henüz yedi yaşındayken Amasya sancak beyliğine gönderilmiştir. Kardeşi Mustafa ile birlikte 1457 baharında Edirne'de sünnet ettirilmiştir. Bayezid Edirne, Amasya, İstanbul, Geyve, Osmancık, ve Saruhan'da pek çok hayrat inşa ettirmiştir. Edirne' deki imaretin temeli 1484 Nisanında atılmış ve bu muazzam eser 1488 yılında bitirilmiştir. Cami, imaret, tabhâne, medrese ve dârüşşifadan meydana gelen külliyenin bulunduğu semte İmâreti Cedîd (günümüzde Yeniimaret) mahallesi adı verilmiş ve Bayezid bu bölgede oturanları avârız-1 
dîvâniyyenin tamamından muaf tutmuştur. Ayrıca Edirne'de Tunca Nehri üzerinde, Osmancık'ta Kızılırmak Nehri üzerinde, Geyve'de ve Sakarya üzerinde birer köprü inşa ettirmiştir.(Turan, 1988, 234-238) Bayezid'in annesi Sitti Şah Sultan da 1482'de "Sitti Şah Sultan Camii'ni inşa ettirmiştir. Sitti Şah Sultan bundan dört yıl sonra vefat etmiş ve yaptırdığı camiin kıble tarafına defnedilmiştir. (Babinger, 2003: 68)

Hekim Ahi Çelebi imareti ile hamamı ve mektebi; Lari, Fazlullah Paşa, Kasımpaşa camileri ve Fazlullah Paşa imareti, Yusuf Paşa camileri de onun döneminde inşa edilmiştir. II. Bayezid İstanbul'dan sıkıldıkça Edirne'ye gelir ve Edirne Sarayı'nda yaşardı. II. Bayezid tahtı oğlu Yavuz Sultan Selim'e bırakınca kalan ömrünü geçirmek üzere yola çıkmış ancak Edirne yakınlarındaki Sazlıdere'de hayatını kaybetmiştir. (Peremeci, 1939: 17-18)

\subsubsection{Yavuz Sultan Selim Dönemi (1512-1520)}

Edirne'yi çok seven Osmanlı hükümdarlarından biri olan Yavuz Sultan Selim, Edirne'ye sık sık gelirdi. Öyle ki yapmak istediği seferlerin plânlarını genellikle Edirne'de hazırladığı bilinmektedir. Çaldıran seferine Edirne' de hazırlanmış ve ordu buradan hareket etmiştir. Yavuz Sultan Selim'in Mısır seferinin hazırlıkları da burada tamamlanmış ve ordu buradan hareket etmiştir. Edirne'ye gitmek için 18 Temmuz 1520'da İstanbul'dan ayrılan Yavuz Sultan Selim surt bölgesinde çıkanbir büyük bir ur (kesin olmamakla birlikte veba yumrusu) nedeni ile Çorlu'dan öte hareket edememiş; doktorların müdahalelerine rağmen vaziyeti gitgide ağırlaşmış ve birkaç ay burada ümitsiz bir tedavi gördükten sonra 21-22 Eylül 1520'de (gece vakti) hayatını kaybetmiştir.

Başta Edirne olmak üzere Trabzon, Kahire ve Şam'daki şehircilik ve imar faaliyetleri haricinde İstanbul'da kendi adını taşıyan camiin temellerini attırmış, fakat tamamlayamamış, Tersane'yi genişletmiş, Sarayburnu ile Sirkeci arasındaki sahilde Mermerköşk veya Yalı Köşkü olarak isimlendirilen bir köşk inşa ettirmiştir.(Emecen, 1988: 414)

\subsubsection{Kanuni Sultan Süleyman Dönemi (1520-1566)}

1520 yılına kadar yedi y1l Manisa'da ikamet eden Şehzade Süleyman, bu zaman boyunca Yavuz Sultan Selim'in seferleri nedeniyle tahta vekalet etme ve koruma vazifesiyle Edirne'de bulunmuştur. (Emecen, 1988: 62) Hükümdarllğı döneminde de İstanbul'daki devlet işlerinden firsat buldukça ailesi ile Edirne'ye gelir ve aylarca burada kalır; komşu devletlerden gelen elçileri sürekli burada huzuruna kabul ederdi. Bunun da sebebi Edirne'nin Kanuni döneminde mimarî ve şehircilik açılarından göz kamaştıran bir güzellikte olmasıdır.(Sannav, 2016) Aynı zamanda bu dönemde Edirne'ye pek çok önemli eser de kazandırılmıştır ki bunların başında: Edirne Ali Paşa Çarşısı, su yolları, Kanuni Köprüsü, Rüstem Paşa hanı, Taşhan, Süleymaniye, Defterdar, Yahya Bey, Şeyh Çelebi camileri gelmektedir ki bunların her biri birer şaheserdir. (Peremeci, 1939: 18-19)

\subsubsection{Selim Dönemi (1566-1524)}

II. Selim'in saltanı sekiz yıl sürmüştür. Hükümdarlık döneminde sefere hiç çıkmamış olan ilk Osmanlı hükümdarıdır. Zamanını yazları İstanbul'da sarayında ve kışın da daha çok Edirne sarayında geçirmiştir. II. Selim yanına topladığı mûsikişinaslar, şairler ve diğer çeşitli zevk ehliyle zaman geçirmiş, şehzadelik dönemlerindeki zevk ve sefa hayatına adeta geri dönmüştür. Bu arada işleri Sokullu Mehmet Paşa yürütmüştür. Dönemin kaynaklarında II. Selim, zevk-ü sefaya düşkün, etrafında âlim ve şairlerin bulunmasından zevk alan, ayrıca güreş̧̧i, müzisyen, cambaz gibi göstericileri yanında bulunduran, cömert, âlicenap bir hükümdar olarak anılagelmiştir. Bununla birlikte halkın arasına pek karışmadığı, babasının sık sık cuma selâmlığına giderek halkın arasına karışmasına karşın onun bunu ihmal ettiği ve sarayda eğlenmeyi tercih ettiği kaynaklarda ifade edilmektedir. Onun cuma selamlığı nedeniyle toplum içerisine pek çıkmaması, ilaveten ordunun başında sefere gitmekten imtina etmesi Osmanlı Devleti'ndeki padişahlık algısında keskin bir farklılaşmayı da beraberinde getirmiştir. Dedesi Yavuz Sultan Selim gibi Edirne’yi çok sevdiği ve 
her firsatta bu şehre gittiği bilinir. Bu hal, muhtemeldir ki onun şehzadelik zamanında burada Edirne'de muhafiz olarak bulunmasından ileri gelmektedir. Kıbrıs'in fethedilmesinin hemen sonrasında II. Selim donanmanın İnebahtı' da uğradığı yenilgi haberini de kışı geçirmek için gittiği Edirne' deyken almış ve yeni bir donanma yapılması emrini yine burada vermiştir. (Emecen, 1988: 418)

II. Selim birçok hayratı ile tanınmıştır. Özellikle Kıbrıs'ın fethinden elde edilen gelirle Edirne'de Mimar Sinan'a yaptırılan Selimiye Camii ve külliyesi bunun en güzel örnekleridir. Edirne'de 1550'li yıllarda yapımına başlanan külliye şehrin tam merkezinde yer almaktaydı. Eski sarayın da bulunduğu alanda, Kavak Meydanı denilen yerde inşa edilen bu külliye geniş bir dikdörtgen avlu içerisinde yer almakta idi. Ortasında cami, güneydoğusunda ve güneybatısında medreseler ile batıda arasta ve Sıbyan mektebinden oluşuyordu. Cami, arastanın doğusundaki dükkânlar ve medreseler Mimar Sinan tarafından 1568-1574 yılları arasında inşa edilmişlerdi ve arastanın batı taraflarında bulunan dükkanlar ile dua kubbesi, tonoz yığılı üst örtüsü ve sıbyan mektebinin II. Selim'in ölümünden sonra III. Murat zamanında Mimar Davut Ağa'ya tamamlattırıldığı düşünülmektedir. Diğer pek çok selâtin camilerinde rastlanan teferruatlı ve oldukça geniş bir külliye planı çerçevesinde bulunmakla birlikte etrafindaki birkaç eser içinde beliren Selimiye, İstanbul'da bulunan Fâtih ve Süleymaniye Camiilerine göre bulunduğu ortamın odak yapısı olarak çok daha fazla dikkat çekmekte ve aynı zamanda da oldukça düz bir topografyada yer almakta idi. Bu durum günümüzde de onu pek çok açıdan ve çok uzaklardan fark edilir hale getirmektedir. (Mülayim, Çobanoğlu, 1988: 430)

II. Selim'in saltanatı döneminde Tunca, Meriç ve Arda nehirleri taşmış ve şehirde dörtyüz kadar ev yıkılarak harap olmuş ve ayrıca tarım arazilerinde de ciddi zararlar oluşmuşstur.(Hibri: 49)

\section{Dönemleri}

1.2.9. III. Murat (1574-1595), III. Mehmet (1595-1603) ve I. Ahmet (1603-1617)

Edirne ticaretinin önemli merkezlerinden olan Arasta Çarş1S1, III. Murat döneminde inşa edilmiştir. Böyle önemli bir çarşının onun döneminde yapılmış olması Edirne'nin öneminin o yıllarda da devam ettiğini göstermesi bakımından önemlidir. (Hibri: 16)

III. Mehmet'in padişahlığı süresince Avusturya üzerine gerçekleştirdiği seferler sonucunda Edirne şehri gerek askerlerin disiplinsiz davranışları ve gerekse şehirde meydana gelen kıtlık nedeniyle bir hayli hırpalanmıştır. Bununla birlikte I. Ahmet' in tahta geçtiği tarihlerde Edirne tekrar eski günlerine dönmeye başlamıştır. Hele de III. Mehmet ve I. Ahmet dönemlerinde Ekmekçioğlu Ahmet Paşa, Mimar Mehmet Ağa ve Mimar Şaban Ağa'ya yaptırdığı Tunca Köprüsü, Yediyol ağzındaki Ekmekçioğlu Han'1 ve sebili gibi şehir kimliğine yeni unsurlar katan eserler, Edirne'nin o dönemde de değerinin devam ettiğini göstermesi bakımından önemlidir. Ayrıca bu tarihlerde üretici ile müşterinin doğrudan doğruya birbirleri ile temasını sağlamak adına yaptırılan Yemişkapanı ve Balkapanı da bu özelliği ile Avrupa'ya örnek olmuş önemli eserlerdendir. (Peremeci, 1939: 19-20)

\subsubsection{Murat Dönemi (1623-1640)}

Tütün ve Kahveyi yasaklayan ve haram sayan Kadızâde Mehmet Efendi'nin de teşvik etmesiyle IV. Murat kahvehaneleri yıktırarak yerlerine bekârlara, nalbant ve debbâğlara mahsus odalar yaptırmış, ayrıca tütünü yasaklamıştır. Zaman zaman Edirne'ye gelmekte olan bu hükümdar tarafindan Edirne'deki kahvehanelerin tamamının yıktırıldığı bilinmektedir.(Yılmazer, 1988: 179) Bununla birlikte onun döneminde Edirne şehri eski önemini kaybetmiş bulunuyordu. Öyle ki; şehrin medreseleri önceden olduğu gibi ilim adamı yetiştiremez hale gelmiş, nadir olarak yetişenler de burada durmayarak daha çok başkente, İstanbul'a gitmeyi tercih eder hale gelmişlerdir. (Peremeci, 1939: 20) 


\subsubsection{Mehmet (Avcı) Dönemi (1648-1687)}

IV. Mehmet döneminde Limni, Bozcaada ve Semadirek adaları Venedik donanması tarafindan 1656'da işgal edilmiştir.(Sannav, 2005) Yine bu tarihlerde Kaptanıderya olan Kenan Paşa'nın, Çanakkale Boğazı'nı muhasara altında tutan Lazaro Mocenigo'nun yönetimindeki Venedik donanması karşısında uğradığı büyük yenilgi de İstanbul'u neredeyse savunmasız bırakmıştır. Hazinenin sıkıntısını ortadan kaldırmak için "imdâdiye" adı ile bir vergi konulmuşsa da bundan beklenen gelir elde edilmemiştir. O sıralarda IV. Mehmet'in yerine tahta kardeşi Şehzade Süleyman'ın geçirilmesini hedefleyen bir komplo da ortaya çıkartılmıştır. Bu komplonun planlayıcısı olan Şeyhülislâm Hocazâde Mesut Efendi, Bursa şehrine sürgün edilir ve orada idam edilir. Mehmet Paşa'nın yerine Mimar Kasım Ağa'nın önerisi ve Vâlide Turhan Sultan'ın kabul ettiği bazı koşullar ile Köprülü Mehmet Paşa 15 Eylül 1656'da getirilmiştir. Bu olaylardan sonra Edirne'de sürekli ikamet etmeye başlayan IV. Mehmet için Mora Yarım adasına ve Teselya'ya kadar uzanan geniş bölgelerde yıllar boyu süre gelecek olan avlanma dönemi başlamıştır.(Özcan, 1988: 414)

IV. Mehmet'in zamanının çoğunu Edirne'de geçiriyor olması şehrin önemini tekrar arttıran önemli bir faktör olmuş; ayrıca Evliya Çelebi'nin Edirne'yi ziyareti de bu dönemde gerçekleşmiştir. Her ne kadar eski şaşalı günlerinden uzaklaşmış olsa da XVII. yüzyıla gelindiğinde Edirne dünyanın en önemli ve en büyük şehirlerinden biri olma özelliğini hala sürdürmekteydi. IV. Mehmet döneminde Köprülüzade Fazıl Ahmet Paşa sadrazam iken Fransa Büyükelçiliği baş tercümanı unvanı ile uzunca bir dönem Türkiye'de ikamet eden Antoine Galland bu dönem Edirne'si hakkında önemli bilgiler vermektedir. 1001 gece masallarını ilk defa Fransızcaya çevirerek büyük bir ün yapan Galland aynı zamanda dikkatli bir gözlemcidir. O, IV. Mehmet'in Edirne'de Selimiye Camii'ne bayram namazına gidişini şöyle anlatmaktadır: “... Alayın baş taraflarında bir yerde Vezir Damat Musahib Mustafa Paşa gidiyordu. Büyük bir gösteriş içerisinde olmasına rağmen, bütün Türk devlet adamları gibi tevazu ile yanyana bir ağır başl1lı̆g 1 vardı. Çevresinde şatırlar yürüyordu. Vezirlerin yanında bulunan bu muhafızların hepsi uzun boylu ve yakışıklı insanlardı. Üniformalarında yeşil, mor, kırmızı ve sarı renkler vardı. Gümüş ve altın tellerle işlenmiş ipek üniformaları güneşin altında parıl parıl yanıyordu. On veya on ikisi yan yana yürüyorlardı. Sonra solak denilen hassa askerleri ilerliyordu. Bunları "çavuş" denilen dokuz padişah yaveri takip ediyordu. Bunlar at üzerinde değil, yaya yürüyorlardı. Her biri elleri ile padişahın bir atını tutuyorlardı. Dokuz at da oldukça gösterişli hayvanlardı. Önde bulunan ilk üç atın koşumları inci ile işlenmişti diğer üç atın ise üzerlerinde elmaslar parlıyordu. Sonraki üç atın koşumları ise som altındandı ve üzerlerine mücevherler işlenmişti. Çavuşları peykler izliyordu. Peyklerin ellerinde altın yaldızlı gümüş baltalar bulunuyordu. Bunların ardısıra padişah geliyordu. Anlatılamayacak derecede güzel gümüş renginde bir ata binmişti. Kavuğundaki sorguçta, balıkçıl tüyleri arasında, çok iri bir elmas parlıyordu."

"Padişahın çehresi, bütün Anadolu halkı gibi esmerce, dolgun, gözleri iri ve manalı idi. Hemen arkasında silahdarı geliyor ve kabzası baştan başa yakutlarla örülmüş kılıcını taşıyordu. Çevresindeki askerlerin giyimi pek göz alıcıydı. İçi samur kaplı elbiselerin düğmeleri elmastı. Böylece Edirne Sarayı'ndan Selimiye Camii'nin kapısına gelindi. Avlularına, caddelere kadar dolu olan camiide bayram namazı kılındı. Dönüşte padişah köprü üzerinden geçerken kendisine doğru bir kadın yaklaştı. Elinde tuttuğu dilekçeyi hükümdara uzattı. Hükümdar hemen atının dizginlerini çekti ve atını durdurarak dilekçeyi okudu. Edirne' deki bizim Fransa Büyükelçiliği binası önünde yabancı bir adam da padişaha dilekçe takdim etmek istedi. Aynı zamanda bir kapıcıbaşı da olan mabeynci, atından indi ve adamın elindeki kağıdı alarak, açmadan padişaha takdim etti. Bu esnada Edirne'de yer ve gökyüzü atılan bayram toplarının sesleri ile inliyordu. 1672 yılının 8 Nisanı olan bugün, bir Cumartesiydi."

“7 Mayıs 1672 günü IV. Sultan Mehmet Polonya seferine çıkmak üzere Edirne’den ayrıldı. Ömrümde şimdi gördügümden daha güzel, daha gösterişli bir alay hiç görmedim. Dünyanın hiçbir yerinde bundan başka bu kadar parlak, düzenli ve zengin bir resmigeçit yapılması söz konusu 
olamazdı. Osmanlı ordusunun padişahın emri altında Edirne'den çıkması, güneşin doğmasından itibaren başlayarak beş saat kadar devam etti. Polonya hududuna kadar olan yerlerdeki Osmanlı birlikleri, orduya yolculuk esnasında katılacaklardı. Yürüyen asker kadar, onların atları da bir o kadar muhteşem gözüküyordu. İnsan seyrederken hayretler içerisinde kalıyordu. Hayvanların üzerinde muhteşem örtüleri bulunuyordu ve ancak başları ve bacakları görünüyor idi. Bir çoğu zırhlı olmakla beraber öyle olmayanların sağrıları kaplan ya da pars postu ile örtülmüşlerdi. Üzerlerindeki sipahiler, kılıç, yay, sırma işlemeli ve içi okla dolu bir okluk taşıyorlardı. Oldukça güzel cilalanmış kalkanları mevcuttu. Tüfek taşıyan askerler, yaya olarak yürüyorlardı. Atlıların bazıları da mızraklıydı."

"İlk birlikler geçip gittikten sonra oldukça kalabalık bir mehter takımı hareket etti. Hem Yeniçeri adımlarıyla yürüyor, hem de nevbet vuruyorlardı. Kösler ve davullar vurduğu zaman yer yerinden oynuyordu. Oldukça ihtişamlı, mucize gibi idiler. Mehter takımının yürüyüşü bittikten sonra bu defa adeta sonu gelmez gibi görünen birlikler hareket ettiler. Askerlerin demirden olan işlemeli zırhları, kırmızı, yeşil ve sarı saten kumaştan sarıkları, ipek kordonlarla süslenmiş olan kadife cepkenleri, oldukça mükemmel imal edilmiş silahları izleyenleri hayretle karışık bir hayranlık duygusu içinde bırakıyordu. Silahlarına o kadar itina gösterilmişti ki, her bir ok, farklı farklı cilalanmış ve süslenmişti. Eskiçağda betimlendiği üzere savaş tanrısı sayılan Mars gökten inip bu manzarayı görse, utanç ve korkusundan, geldiği yere derhal dönerdi.”(Öztuna, 1989: 321)

Galland'ın da ifadelerinden anlaşıldığı üzere bu dönemde Edirne, yine İstanbul'u kıskandıracak kadar mamur bir hale gelmiştir denilebilir. Özellikle de Köprülüzade Fazıl Ahmet Paşa günlerinde burada şehzade Mustafa ve Ahmet'e yapılan sünnet dügünleri ve sultanlara yapılan düğünler Edirne'ye eski günlerini hatırlatırcasına oldukça parlak ve şaşalı günler yaşatmıştır. Şair Nabi meşhur "sûrnâme"sini 1674'de bu düğün için kaleme almıştır.

IV. Mehmet zamanında Edirne'de "Hıdırlık Sarayı" ile Buçuktepe' de bir saray yaptırılmışsa da günümüze kadar ulaşmaları mümkün olmamıştır. (Akç11, 1988: 126)

IV. Mehmet'in son zamanlarında meydana gelen Viyana yenilgisi, aynı zamanda Edirne için de karanlık günlerin başlangıcı olmuşsa da Edirne, yine bütün Avusturya seferlerinin hareket merkezi olmaya devam etmiştir. (Peremeci, 1939: 23)

\subsubsection{Ahmet Dönemi (1691-1695)}

25 Şubat 1643 yılında dünyaya gelen II. Ahmet, aynı zamanda kardeşi de olan II. Süleyman'ın yerine, 23 Haziran 1691'de 49 yaşındayken Edirne'de tahta çıkmıştır. Bu esnada Osmanl1-Avusturya savaşları sürüp gitmekteydi. Malta ve Papalık gemilerinin 21 Eylül 1695 'te Sakız Adası'na asker çıkararak adayı işgal etmelerine oldukça üzülen II. Ahmet, adanın geri alınması için hemen hazırlıklara başlanmasını emretmişse de çok geçmeden, 6 Şubat 1695 tarihinde elli iki yaşındayken istiska (ödem) adı verilen hastalığı nedeniyle Edirne'de hayatını kaybetmiş ve cenazesi İstanbul'a nakledilerek Kanûnî Sultan Süleyman'ın türbesinin olduğu mahale defnedilmiştir.(İlgürel, 1988: 34)

\subsubsection{Mustafa Dönemi (1695-1703)}

2 Haziran 1664 tarihinde Edirne'de dünyaya gelen II. Mustafa'nın doğumu dolayısıyla Edirne Sarayında yedi gün ve yedi gece şenlik yapılmıştır. 6 Haziran 1675'te kardeşi Ahmet ile birlikte yine Edirne'de düzenlenen muhteşem şenliklerde sünnet olmuştur. 1687'de babasının tahttan indirilmesi sırasında babası tarafından tahta namzet gösterilmiş olsa da devletin ileri gelenleri padişahlığa II. Süleyman'1 uygun görmüş; bunun üzerine Şehzade Mustafa, kardeşi Ahmet ve babas1 ile beraber Topkapı Sarayı'nın Şimşirlik Dairesi’ne kapatılmıştır. Ancak sonrasında Edirne'ye gönderilmiştir. 1691'de II. Süleyman'ın vefatıyla tahta geçmesi yeniden gündeme gelmiş, bu defa da Sadrazam Köprülü Fâzıl Mustafa Paşa, II. Ahmet'in padişah olmasını arzu etmiştir. Sultan Ahmet'in vefatından sonra Sadrazam Sürmeli Ali Paşa taht namzeti olarak Sultan Ahmet'in oğlu İbrâhim'i 
göstermişse de Mustafa, Hazinedarbaşı Nezir Ağa ile başka devlet adamlarının desteğini alarak hânedanın en büyügü sıfatıyla 6 Şubat 1695'te Edirne Sarayı'nda 31 yaşında vezîriâzam ve şeyhülislâmı beklemeksizin padişahlığını ilân etmiştir. Sonrasında da Eskicami' de kılıç kuşanma merasimi düzenlenmiştir.

II. Mustafa tahta geçince planlarını hızlı bir şekilde uygulamaya çalışırken önceden Venedik kuvvetlerinin eline geçmiş olan Sakız adası Venediklililerden geri alınmıştır. Sakız'ın geri alınmasının uğur getireceğine inanılmış ve Edirne'de bu nedenle büyük şenlikler tertip edilmiştir.(Özcan, 1988: 276)

1699'da imzalanan Karlofça Antlaşması'ndan sonraki beş yıllık süreçte pek çok askerî ve malî önlemler alınırken II. Mustafa gerek askerler, gerek halk ve gerekse ilim adamları tarafindan ciddi bir reaksiyon ile karşı karşıya kalmıştır. Hükümdarın uzlete çekilmesi ve vaktini Edirne'de geçiriyor olması, yeniçeri ocağında ve reayada adeta babası gibi davranmaya başladığı dedikodularının yayılmasına neden olmuştur. Sultan Mustafa saltanatının ilk yıllarında kendini tamamiyla devlet işlerine vermişse de sonraki süreçte arzu edilen iradeyi gösterememiş olması ve savaşlar sırasında tek başarısının sadece rakiplarinin devlet hudutları içerisine girmesini önlemek olması halkta ve sarayda bazı huzursuzluklara neden olmuştur.(Kantemir, 1980: 297)

Esasında barış dönemine bulunulmasına rağmen muharebelerden arzu edilen zaferlerin elde edilememiş olması ve toprak kayıpları nedenleriyle reayada meydana gelen hoşnutsuzluğun padişahın doğrudan şahsını hedef alacak mertebeye ulaştığı anlaşılmaktadır. Bu olumsuz şartlarda meydana gelen tepkiler "Edirne Vak'ası" veya "Edirne Olayı" denilen isyanların başlamasına yol açmıştır. İsyanın görünürdeki hedefi, aynı zamanda padişahın hocası da olan ve devlet işlerine çokça müdahale eden Şeyhulislam Feyzullah Efendi idi. Nitekim o tarihlerde Gürcistan'a gönderilmesi düşünülen 200 kadar cebeci askeri, kendilerine ödenmemiş ulûfelerini talep etmeleri gerekçesi ile ayaklanmış ve böylelikle İstanbul'da duruma hakim olan isyancılar Edirne'ye arzularını belirten bir mahzar göndermişler ve Şeyhülislâm Feyzullah Efendi'nin bu mahzarı padişaha zamanında ulaştıramamasını fırsat bilen Rami Mehmet Paşa da şeyhulislamı görevinden azlettirmiş̧ir. Bu gelişmelerden haberi olmayan isyancılar Edirne'ye doğru hareket ederek saltanat değişikliği yapmak istemişler ve hocası Mehmet Efendi'nin önerisi ile Şehzade Ahmet'in tahta çıkmasını kararlaştırmışlardır. Edirne hükümetini temsilen orada bulunan vezir Hasan Paşa ile İstanbul'un temsil eden Ahmet Paşa'nın gayret ve çabaları ile bu mesele çatışma olmaksızın hal yoluna konulmuştur. Edirne'den buraya gelenlerin İstanbul'dan gelenlere katılımı ile yalnızlaşan II. Mustafa, yanındaki saray ahalisi ve vezirleri ile birlikte Edirne' ye geri dönmüştür. 22 Ağustos 1703 tarihinde kardeşi Ahmet'in bulunduğu yere giderek, "Birader! kul seni hünkar olarak görmek istemiş" diyerek kendi rızasıyla tahtı kardeşine bırakmıştır. (Özcan, 2000: 248)

İktidara geldiği günden sonra sekiz sene altı ay ve on yedi gün padişahlık yapan II. Mustafa, aynı zamanda orduları ile sefere çıkan son Osmanlı padişahı olmuştur. "Mesane" ve "istiska" hastalıklarına yakalanmış ve bu rahatsızlıklarına son yaşananların verdiği kederler ve üzüntüler de eklenince tahttan indirilmesinden beş ay kadar sonra çok sevdiği Edirne' de 29 Aralık 1703 tarihinde vefat etmiştir. Edirne'de onun döneminde Saraçhane Köprüsü'nün önemli bir onarımdan geçtiği bilinmektedir.(Özcan, 1988: 279)

\subsubsection{Ahmet Dönemi (1703-1730)}

IV. Mehmet'in oğlu III. Ahmet aynı zamanda II. Mustafa'nın da kardeşidir. 31 Aralık 1673 tarihinde dünyaya gelmiştir. 1703'te meydana gelen Edirne Vakası esnasında, II. Mustafa'yı tahtından hal etmek için Edirne'ye doğru yürümekte olan cebecilerin kendi aralarında müftü olarak atadıkları Mehmet Efendi'nin zorlamasıyla, 17 Ağustos 1703 tarihinde isyancılar tarafından hükümdar yapılmasına hüküm verilmiş ve hemen sonrasında da Çorlu'da onun ismine hutbe okutulmuştur. 22 Ağustos'ta, isyancıların sadrazam olarak tayin ettikleri Kavanoz Ahmet Paşa 
marifetiyle Edirne Sarayı'ndan getirtilerek kendisine biat töreni gerçekleştirilmiştir. Böylelikle fiili olarak tahta çıkan III. Ahmet'in ilk işi kendisinden önceki padişah II. Mustafa ve çocuklarının Edirne Sarayı'na gönderilmesi ve buraya kapatılmasına dair fermanı çıkartmak ve Dârüssaade ağası olan Nezir Ağa'yı görevinden azletmek olmuştur. (Aktepe, 1988: 34)

III. Ahmet'in saltanatının ilk dönemlerinde Edirne pek çok bakımdan önemini korumaya devam etmişse de Pasarofça Antlaşmasının imzalanmasından sonra hükümdar İstanbul'a çekilince Edirne de eski öneminden uzaklaşmaya başlamıştır. III. Ahmet'in Edirne'de bulunduğu dönemlerde buraya gelmiş bulunan ve bir müddet kalan İngiltere elçisi Mösyö Montequ'nun eşi Madam Montequ Türkiye'den yazdığı mektupların bazılarını burada kaleme almıștır. Madam Mantequ'nun, o dönem Edirne'sinde ticaret hayatı ve Yahudi Cemaati, Türk kadınının toplum içerisindeki yeri ve Selimiye Camii hakkında verdiği bilgiler önemlidir.(Montequ, 1977)

\subsubsection{Mahmut Dönemi (1730-1754)}

I. Mahmut 2 Ağustos 1696'da Edirne'de doğmuştur. Kendisi aynı zamanda II. Mustafa'nın en büyük oğludur. Annesi Sâliha Sultan'dır. Şehzade Çocukluk yıllarını Edirne'de geçirmiş ve ilk tahsilini burada görmüştür. (Anonim: 146) Babasının iktidardan düşürülmesiyle sonuçlanan $(1115 / 1703)$ Edirne Vakası'nın sonrasında kardeşleri ile beraber İstanbul'a getirilmiştir. Yirmi yedi yıl kadar sürmüş olan kafes yaşamının sonrasında Patrona Halil İsyanı ile III. Ahmet'in tahttan feragat etmesi üzerine 2 Ekim 1730’te kendisi tahta çıkmıştır.(Özcan, 1988: 348)

I. Mahmut'un döneminde, 1746 'da Edirne'de Üçşerefeli Camii civarlarında büyük bir yangın çıkmış ve bütün o bölgeyi yaktığı gibi Ağaç Pazarı denilen alana kadar yayılmış; diğer başka bir koldan da İstanbul yolunda Kanatlı köprü denilen mevkie kadar ilerlemiştir. Öyle ki yangından Eski Camii dahi kısmen etkilenmiştir. Yaklaşık yedi saat kadar süren bu yangında konaklar da dahil olmak üzere Edirne'nin 30 kadar mahallesi neredeyse tamamen yanmıştır. Bu tarihlerde Edirne'de toplam 160 mahalle bulunmaktaydı.1752'de de Edirne'de o güne kadar tanık olunmamış bir deprem meydana gelmiş, yüzden fazla insan hayatını kaybetmiş, neredeyse bütün evler zarar görmüş, pek çok cami, han, hamam yıkılmıştır. Bu olaylardan sonra Edirne şehri daha da gözden düşmüş, şehir küçülmüş ve giderek harap bir hal almaya başlamıştır. (Peremeci, 1939: 26-27)

\subsubsection{Selim Dönemi (1789-1807)}

24 Aralık 1761 doğan III. Selim'in babası III. Mustafa, annesi ise Mihrişah Sultan'dır. Özellikle babası zamanında itinalı bir eğitim gören hükümdar, babasının Tophane ile Tersane'ye düzenlediği denetim gezilerine henüz çocuk yaşlarındayken katılmıştır. Aynı zamanda dedesi olan III. Ahmet' in huzuruna elçi kabulleri sırasında yanına evlatlarını alması örneğini takip etmekte olan hükümdar, söz konusu törenlerde şehzade Selim'i de yanında bulundurarak elçiler ile tanışmasını ve devlet mekanizmasını öğrenmesini temin etmiş ve böylelikle oğlunu devlet işlerine alıştırmıştır. Selim'in sslahatçı fikirlerini babasından kalan bir miras olarak küçük yaşlarda edindiğini ifade etmek esasında yanlış olmaz. 7 Haziran 1789 tarihinde tahta çıktığında devletin aksayan yönlerini görebilmiş ve Avrupa normlarında eğitilimli ve donanımlı Nizam-1 Cedid adı ile bir ordu kurulması için çaba sarf etmiştir.(Beydilli, 1988: 421) Bu ordunun kuruluş aşamasında Edirne'de de bir Nizam ocağı açılacak olmuş ve bu iş için Kadı Abdurrahman Paşa memur edilmiştir. Fakat eski düzen taraftarları Balkanlardaki Derebeylerinden de destek alarak ayaklanmışlar ve buna firsat tanımamışlardır. Kadı Abdurrahman Paşa Çorlu'ya kadar gelmişken geri dönmek mecburiyetinde kalmıştır. (Peremeci, 1939: 27) Sonraki süreçte Şeyhülislam Topal Ataullah Efendi ve Köse Mûsâ Paşa tarafindan düzenlenen yeni düzene karşı isyan Boğaz yamakları marifetiyle başlatılmış (Kabakçı Mustafa İsyanı) ve dört gün sürmüş ve çok kan dökülmeksizin III. Selim'in iktidardan indirilmesiyle neticelenmiştir (25-29 Mayıs 1807). (Beydilli, 1988: 423) asiler III. Selim'in yerine IV. Mustafa'yı iktidara getirmişlerdir. 1808'de Alemdar Mustafa Paşa, Tuna boyundan topladığı ordusu ile Edirne'de bulunan Sadrazam Çelebi Mustafa Paşa'nın yanına hareket etmiş ve İstanbul'a 
gidip IV. Mustafa'yı tahttan indirmek ve III. Selim'i tekrar tahta çıkarmak planlarını Edirne'de hazırlamıştır. Fakat sonraki süreçte Alemdar Mustafa Paşa'nın öldürülmesi ile Edirne, derebeylerinin elinde kalmaya devam etmiştir. (Peremeci, 1939: 27)

\subsubsection{Mahmut Dönemi (1808-1839)}

20 Temmuz 1785'te doğan II. Mahmut, I. Abdülhamit'in oğludur. Aynı zamanda amcası da olan Sultan III. Selim'in 29 Mayıs 1807'de iktidardan düşürülmesiyle, ağabeyi IV. Mustafa'nın tahta çıkması ve bunun da Alemdar Mustafa Paşa tarafından indirilmesiyle 28 Temmuz 1808'de padişah olmuştur. (Beydilli, 1988: 352)

II. Mahmut'un Yeniçeri Ocağını lağvettiği dönemde Edirne'de Yeniçerilerin neredeyse tamamı sorunsuz bir şekilde ortadan kaldırılmış ve yeni ocağın oluşturulmasına başlanılmıştır. Ancak 1821 'de Mora Yarımadası'nda meydana gelen ayaklanma sonrası gelişen olaylar sonucunda Rumlar bağımsızlık ilân etmişler ve Rumların bağımsızlığına destek olan Fransa, İngiltere, ve Rusya'nın müdahale etmeleri sonucunda esaslı bir Avrupa sorununa dönüşmüş olan bu ayaklanmanın arkasından Ruslar, Akkirman Antlaşmasıyla (7 Ekim 1826) Sırbistan ve Eflak-Boğdan kendilerine verilmiş olan ayrıcalıkların artırılmasını Osmanlılar'a kabul ettirmişlerdir. Ayrıca bu devletler Bâblâli'ye birer nota vermişler ve Yunanistan'ın Osmanlı Devleti'ne bağlı ancak iç işlerinde bağımsız hareket edebilen bir devlet olmasını talep etmişler, istekleri kabul görmeyince de ortak donanmaları ile Navarin'deki Osmanlı gemilerini yakmışlardır (20 Ekim 1827). (BOA.HAT, nr. 899/36496, H. 24.05.1243-M.13.12.1827) Kendilerinden tazminat istenince de İstanbul'daki elçilerini geri çekmişlerdir. Rusya ise Bâbıâli’nin yayımladığı bildiriyi bahane ederek Osmanlı Devleti'ne karşı savaş ilan etmiştir (26 Nisan 1828). Savaşın ilerleyen safhalarında Edirne önündeki Rus kuvvetleri 22 Ağustos 1829 'da hiç bir direniş ile karşılaşmadan şehre giriş yapmışlar, ayrıca Lüleburgaz ve Kırklareli’ni de işgal etmişlerdir. Rusya Yunanistan'ın söz konusu bağımsızlığı ile Eflak-Boğdan ve Sırbistan'dan imtiyazlarının genişletilmesi haricinde oldukça ağır bir tazminat ödenmesini ve bu meyanda Anadolu'da bulunan bazı kalelerin kendilerine terk edilmesini talep etmiştir. Yapılan görüşmelerden sonra Edirne Muahedesi, 14 Eylül 1829 Pazartesi günü imzalanmıştır. Bu muahede sonucunda Osmanlı Devleti Yunanistan'ın bağımsızlığını kabul etmek mecburiyetinde kalmıştır.(Danişmend, 1972: 115)

1829'da Edirne'de kuvvetli bir deprem meydana gelmiş ve bu depremde 21 adet minare yıkılmıştır. (BOA, HAT, 1083/44111, H. 10.10.1244-M. 15.04.1829) Rusların Edirne'yi işgali sonrasında Edirne'de 1832'de büyük bir taun (veba) hastalığ ortaya çıkmış ve bu hastalığın hızlı bir şekilde yayılması sonucunda Edirne nüfusu oldukça azalmıştır. Rusların Edirne'yi boşaltmalarından sonra uzunca bir süre şehre verdikleri zararın giderilmesine çalışılmıştır.(Peremeci, 1939: 30)

\subsubsection{Abdülmecit (1839-1861), Abdülaziz (1861-1876) Dönemleri}

Abdülmecit döneminin en önemli gelişmesi 1839'da Tanzimat'ın ilan edilmesidir. (BOA, İ.MSM, nr.1/5, H.01.12.1255-M.05.02.1840). Tanzimat'ın ilanının İmparatorluğun pek çok bölgesinde olduğu gibi Edirne'de de özellikle Hristiyan ve Musevî reaya adına önemli yansımaları olmuştur. Özellikle de askerlik vergisi vermek suretiyle gayrimüslimlerin askere gitmemelerine karşın Müslüman halkın süresi ortalama olarak 7-8 yıl, hatta bazen 10 yıl süren askerlik mükellefiyetlerini yerine getirmeleri ciddî sıkıntıların meydana gelmesine sebep olmuştur. Bununla birlikte II. Mahmut döneminde yapılması planlanmış olan Meriç köprüsü Abdülmecit döneminde yaptırılmıştır. (BOA, A.MKT, nr.1-20, H.16.04.1256 M.17.06.1840). Ayrıca Türkiye'de ilk telgraf 3 Mayıs 1856'da Abdülmecit döneminde Edirne'den İstanbul'a gönderilmiştir.(Sannav, 2011:319) Abdülaziz döneminde de Avrupa demiryolu yapılmış ve Edirne demiryolu ile İstanbul'a bağlanmıştır. (BOA, HR.SYS, nr. 216/30, M.1857) Yine bu dönemde Hurşit Mehmet Paşa'nın Edirne valiliği sırasında, vilayet dairesinde vilayet matbaası yapılarak ilk Edirne gazetesi basılmaya başlanmıştır.(Efendi, 2013: 731) 


\subsubsection{Abdülhamit Dönemi (1876-1909)}

II. Abdülhamit'in tahta geçtiği (BOA, Y.PRK.HR, nr. 1/7, H.19.10.1293 M.7.11.1876) tarihlerdeki en önemli olay 93 Savaşı olarak da adlandırılan 1877-1878 Osmanlı Rus Savaşıdır. BOA,Y.PRK.ZB, nr.1/9, H.23.02.1296-M.16.02.1879,lef:13) Gerek Balkanlarda ve gerekse Kafkaslarda Osmanlı Devleti'nin aleyhine pek çok hadise yaşanmış ve bu savaştan Edirne ve Edirne halkı oldukça etkilenmiştir. Rus orduları Plevne'yi ele geçirdikten sonra sırasıyla Sofya ve Filibe'yi işgal ederek Edirne üzerine yürümüşlerdir. II. Abdülhamit, Plevne'nin düşmesinden sonra Rusya'ya barış teklif etmişse de bu teklif Ruslar tarafindan geri çevrilmiştir.(Karal, 1975: 268-269) Rus ordularının Edirne'ye gireceğinin anlaşılması üzerine (BOA,Y.EE, nr. 84/113, H.17.01.1295 M.21.01.1878) Edirne Valisi olan Namık Paşazade Cemil Paşa ile Müşir Ahmet Eyüp Paşa'lardan birisinin buyurduğu emir ile 18 Ocak 1878'de saray tamamen ateşe verilmiş ve çıkan yangın yaklaşık üç gün kadar devam etmiştir. Rusların işgalinden kurtulmasından sonra Edirne sarayının bazı yanmamış kısımlarındaki kıymetli parçalar ile çiniler Vali Rauf Paşa marifetiyle yabancılara bağışlanmıştır. Bu ve benzeri şekilde yağma ve talan edilerek yok edilen parçaların 27 sandık olduğu ifade edilmektedir. Hacı İzzet Paşa 1884 yılında yeniden Edirne valisi olmuş ve sarayı ihya etmek istemiştir. Ancak arzusunu gerçekleştirmek mümkün olamamış, kendisini takip eden valiler de Edirne' de yapılan kışlalar ile diğer kamu binaları için ihtiyaç duyulan sarf malzemelerinin saraydan arta kalan harabeden alınmasını uygun gördükleri için kısa bir süre sonra kalıntılar da yok olup gitmiştir.(Eyice, 1988: 433)

Ruslar Edirne'ye girdikten sonra Türklere oldukça eziyet etmişlerdir. Öyle ki Bâdi Efendi'nin Riyâz-1 Belde-i Edirne isimli eserinde yazdığı üzere Türk köylerinin ve kasabalarının neredeyse tamamı yakılıp yıkılmıştır. Sadece Edirne'nin Kıyık, Kirişhane, Yeniimaret ve Yıldırım mahallelerinde iki binden fazla Müslüman evi yıkılmış, camii ve tekke gibi binalara da epeyce zarar verilmiştir. Ruslar buralarda bulunan pek çok kıymetli ve tarihi önemi olan eseri Rusya'ya taşımışıtır.(Efendi, 2013: 686)

Ruslar Edirne'ye ikinci girişlerinde 445 gün kalarak şehrin kültür tarihine önemli zararlar vermişlerdir. Selimiye Camii'nin Hünkâr mahfilinde bulunan çiniler başta olmak üzere pek çok camideki çinileri ve başka Türk sanat eserlerini sökerek Rusya’ya götürmüşlerdir.

Berlin Antlaşması'ndan sonra, 13 Mart 1879'da Edirne tekrar Osmanlı Devleti'nin eline geçmiştir. Edirne 1903'deki Bulgar İsyanı haricinde, 1877-78 savaşını takip eden yaklaşık 30 yıllık süreçte savaş görmemiş ve barış içerisinde yaşamıştır.

\subsection{1. İşgal Yıllarında Edirne}

Edirne, üçüncü kez 1913'te işgal edilmiştir. (BOA, DH.İ.UM. nr. 86/80, H.28.02.1332, M.26.01.1914) 22 Eylül 1912 tarihinde Bulgaristan, Sirbistan, Romanya, Yunanistan ve Karadă temsilcileri, Sofya' da toplanmışlar ve saldırıya dönük bir anlaşma imzalamışlardır. Buna göre söz konusu devletler, Ekim ayı ortalarında Osmanlı Devleti'ne saldırmışlardır. 9 Ekim 1912'de de Bulgarlar'ın Edirne saldırısı başlamıştır. Edirne Müdafii Şükrü Paşa'nın komutasında gerçekleşen Edirne Savunması'nda, Şükrü Paşa, her türlü yokluğa rağmen şehri altı aya yakın süre müdafaa etmiştir. Ancak şehir kahramanca müdafaa edilmesine rağmen 26 Mart 1913'te Bulgarlar'a teslim edilmek zorunda kalınmıştır.

1877-78'de meydana gelen Osmanlı-Rus Savaşı sebebiyle yapılan ve son defa Balkan savaşlarında kullanılan Edirne Tabyalarının en büyük olanı Hıdırlık Tabyası'dır. Bundan başka önemli bir Tabya olan Kıyık Tabyası, Balkan Savaşı Müzesi haline getirilmiş ise de tarihî açıdan Hıdırlık Tabyası çok daha önemlidir. Hıdırlık Tabyası'nı Edirne Savunma günleri esnasında Edirne müdafii Şükrü Paşa karargah olarak kullanmıştır. Hıdırlık Tabyası, Edirne düşmana teslim edildiğinde beyaz renkli teslim bayrağının direğe çekildiği tarihi yer olarak da hatırlanılmaktadır.(Usal: 46) 
I. Balkan Savaşı sonucunda Edirne, Bulgaristan'a terkedilmiştir. Ancak söz konusu dört Balkan devleti savaşın neticesinde Osmanlı İmparatorluğu'ndan elde ettikleri toprakları paylaşmakta anlaşamamış ve bu defa da kendi aralarında savaşa tutuşmuşlardır. Bulgaristan, kısa bir müddet sonra Sırbistan ve Romanya'nın saldırısına uğramış ve Edirne'den çekilmek zorunda kalmıştır.(Alp, 1987: 5; Alp, 1989) Bu durumdan yararlanan Babıali harekete geçmiş ve Enver Paşa'nın komuta ettiği Osmanlı birlikleri 21 Temmuz 1913 tarinde Edirne’yi Bulgar işgalinden kurtarmıştır. 29 Eylül 1913 tarinde imzalanan İstanbul Anlaşması ile de fiilen belirlenen durum resmî bir hale gelmiştir. (Sarınay, 2012: 303)

Edirne, I.Dünya savaşı sonrasında başka bir önemli olaya şahit olmuştur. Yunanistan Devleti'nin Mondros Mütarekesini takip eden günlerde Anadolu ve Trakya'da başlatmış oldukları işgal girişimleri, Edirne başta olmak üzere 25 Temmuz 1920 tarihinde tüm Doğu Trakya'nın işgali ile neticelenmiştir. Böylece Edirne, son kez iki yılı aşkın bir süre boyunca Yunanistan'ın işgali altında kalmıştır. Kuvvay-1 Milliye'nin göstermiş olduğu kuvvetli direnç ve Yunan askerlerinin Sakarya'da uğramış olduğu ağır mağlubiyet, İtilaf Devletlerini 1922 yılında tavır değiştirmeye zorlamıştır. Bunun üzerine 1922'nin Mart ayında toplanan Paris Konferansı, Kırklareli ve Edirne haricindeki, tüm Doğu Trakya topraklarının Türklere geri verilmesini tavsiye etmiştir. Ancak Edirne'nin işgal altındaki vaziyetinin devamını öngören bu tasarı, Ankara Hükümeti tarafindan kesin bir şekilde reddedilmiştir. Büyük Taarruz'un zaferle sonuçlanması bütün Türk Milletinin olduğu gibi Edirne'nin de makus kaderini değiştirmiştir. Buna göre 11 Ekim 1922 tarihinde imzalanan Mudanya Mütarekesi ile Yunan Devleti Karaağaç Mahallesi de dahil olmak üzere Meriç'in batısına kadar Doğu Trakya'nın tamamından çekilmeyi kabul etmiş; yerlerine geçen itilaf birlikleri de söz konusu bölgeyi, bir ay içerisinde Türk kuvvetlerine bırakmaya taahhüt etmiştir.

1922 yılının 14 Ekiminde Mudanya Mütarekesi yürürlülüğge girmiş ve 1922 yılının 25 Kasımında Türk askerleri Edirne'ye ayak basmıştır. Lozan Konferansı'nda alınan karar gereğince, Karaağaç Mahallesi (BOA, HR.İM, nr. 19/76, M.05.06.1923) ve Karaağaç İstasyonunun Yunanlılarca terk edilmesinden sonra (15 Eylül 1923), Trakya gerçek anlamda işgalden kurtulmuş ve günümüzdeki sınırlara ulaşılmıştır. Edirne, böylelikle Türkiye Cumhuriyeti'nin bir serhat şehri haline gelmiştir. (Usal: 47-48)

Edirne ve bütün Trakya'nın Yunan işgalinden kurtulması için Trakya-Paşaeli Müdafaa-i Hukuk Cemiyeti oldukça önemli gayretlerde bulunmuştur.(Aykut, 2010: 92) Çalışmaları ve hedefi Batı Trakya'yı da içine alacak şekilde olan bu dernek Avukat Şeref (Aykut) Bey, Edirne Milletvekili Faik (Kaltakkıran) Bey, Belediye Başkanı Şevket Bey, Yolageldili Kasım Bey’lerin öncülüğünde 2 Kasım 1918'de, henüz ateşkes anlaşması imzalanmadan önce kurulmuştur. "Trakya" isimli bir gazete çıkartan cemiyet üyeleri Trakya'nın Yunanistan'a verileceği haberleri üzerine 1919 yılı yaz aylarından itibaren bir dizi kongreler düzenlemiş ve Paris'e temsilciler göndererek tüm Trakya'nın Türk Milletine ait olduğu gerçeğini dile getirmeye çalışmıştır.(Bıyıklığlu, 1978: 123-167)

Sonuç olarak ifade etmek gerekirse Edirne tarih boyunca önem ve değerini her zaman muhafaza etmiştir. İlkçağda Orta Asya'dan göç yoluyla Edirne ve yöresine yerleşen Traklar tarafindan kurulmuş olan kent sonraki dönemde, Makendoyalı Büyük İskender döneminde Romalı imparator Hadrianus tarafindan yeniden imar edilmiş ve yeniden kurucu imparatoru olan Hadrianus adına "Hadrianapolis" olarak anıla gelmiştir. Edirne bir dönem Bulgarların egemenliğine geçmiş, ancak 1361 'de I. Murat döneminde fethedilinceye kadar Bizans'ın hakimiyetinde bulunmuştur. 1453'deki İstanbul'un fethine kadar kadar geçen 92 y1l boyunca Osmanlı İmparatorluğu'nun başkenti olmuş ve sonraki asırlarda "Paşa Sancağı" ismi ile Rumeli Beylerbeyliği'ne bağlı bir vilayet haline dönüştürülmüştür. XII. Yüzyılda İmparatorluğun üniversite kenti olarak tanınmış ve Avrupa'nın en önemli ve en büyük birkaç şehrinden biri haline gelmiştir. Tarihi boyunca Edirne kültür ve medeniyet olaylarının çokça yaşandığı tarihi bir şehir olma özelliğinde olmuştur. Öyle ki; Mimarî yenilikler bu kentin birbirinden güzel ve özenli olarak inşa edilen yapıları ile İmparatorluğa girmiş;; 
döneminin süsleme ve hat sanatının en müstesna misalleri bu şehirde verilmiş ve çok sayıda nitelikli medreseleri en çetin ilmî münakaşa ve münazaralara şahit olmuş, Osmanlı' da tıp literatürüne geçecek olan ilk uygulamalar bu şehirde başlamıştır. Asıl hüviyetini bilim ve teknikte ilerlemiş olduğu Osmanlı döneminde bulan ve imparatorluğun İstanbul'dan sonra gelen en önemli şehri olan Edirne, tarihi boyunca medeniyet mirasımızın en fazla olarak hissedildiği bir şehir olma başarısını göstermiştir.

\section{KAYNAKÇA}

\section{Arşiv Belgeleri}

Dahiliye Nezareti İdare-i Umumiye Evrak1 (DH.İ.UM.), nr. 86/80.

Hariciye Nezareti Siyasi (HR.SYS), 1186/6; 216/30.

Hat-1 Hümayûn, (HAT), nr. 899/36496.

İrade Mesail-i Mühimme (İ.MSM), nr.1/5.

Sadaret Mektubi Kalemi Evrakı (A.MKT), nr.1-20.

Yıldız Esas Evrakı (Y.EE), nr. 84/113.

Yıldız Perakende Evrakı Hariciye Nezareti Maruzatı (Y.PRK.HR), nr. 1/7.

Yıldız Perakende Evrakı Zabtiye Nezareti Maruzatı (Y.PRK.ZB), nr.1/9.

\section{Kitap ve Makaleler}

Akç11, N.Çiçek. (1988). Sarây-1 Cedîd, , c. 36. DİA.

Aktepe, M. (1988). Ahmed III, c. 2. DİA.

Alp, İ. (1990). Belgeler ve Fotoğraflarla Bulgar Mezâlimi (1878-1989), . Ankara: Trakya Üniversitesi Yayınları,

Alp, İ. (1989). Bulgar Zulmünü Günümüze Kadar İntikal Ettiren Edirne ve Çevresindeki Şehitlikler. Ankara: Sevinç Matbaası.

Armaoğlu, F. (1975). Siyasî Tarihi (1789-1960), . Ankara: Kronik Kitap.

Aykut, M. Ş. (2010). Trakya'da Milli Mücadele Tarihi Malta Hatıratı ve Malta'da Türkler. (H. B. Dilan, Ed.) İstanbul.

Ayverdi, S. (1939). Türk Tarihinde Osmanlı Asırları. İstanbul: Kubbealtı Neşriyatı.

Babinger, F.(2003). Fatih Sultan Mehmed ve Zamanı, İstanbul: Oğlak Yayınları

Beydilli, K. (1988). Mahmut II (Vol. 27). DİA.

Beydilli, K. (1988). Seim III (Vol. 36). DİA.

Biyıkoğlu, T. (1978). Trakya'da Milli Mücadele. Ankara: TTK.

Danışmend, İ. H. (1972). Osmanlı Tarihi Kronolojisi. İstanbul: Türkiye Yayınevi.

Efendi, Ahmed Bâdî. (2014), Riyâz-1 Belde-i Edirne, Hazırlayanlar Niyazi Adıgüzel-Raşit Gündoğdu, , İstanbul: Trakya Üniversitesi Yayınları

Emecen, F. (1988). İstanbul- İstanbul'un Fethi (Vol. 6). DİA.

Emecen, F. (1988). Süleyman I (Vol. 38). DİA.

Emecen, F. (1988). Selim I (Vol. 36). DİA. 
Eyice, S. (1988). Edirne, , c. 10.DİA

Gökbilgin, M. T.(2016). Kanunî Sultan Süleyman, yayına hazırlayan Sabri Can Sannav, , İstanbul: Trakya Üniversitesi Yayınları

Hibri, A. (1996). Enisü'l-Müsâmirin, Edirne Tarihi 1360-1650. (R. Kazancıgil, Trans.) Edirne.

İlgürel, M.(1998): Ahmed II, c. 2, DİA.

İnalcık, H.(1993) Edirne'nin Fethi, Edirne'nin 600. Fethi Yıldönümü Armağan Kitabı, Ankara: TTK,

İnalc1k, H. (1988). MEHMET II. DİA.

İnalc1k, H.(1988), Mehmed I, , c.28.DİA

Kantemir, D. (1980), Osmanlı İmparatorluğunun Yükseliş ve Çöküş Tarihi (trc. Özdemir Çobanoğlu), c. III Ankara:

Karal, E, Z. (1988). Osmanlı Tarihi, Ankara: TTK

Lamartine, A. D. (2011). Osmanlı Tarihi. (S. Bayram, Trans.) İstanbul: Kapı Yayınları.

Lady, M. (1977). Türkiye Mektupları 1717-1718, (trc. Aysel Kurutluoğlu), İstanbul: Tercüman 1001 Temel Eser

Mülayim, S. -Çobanoğlu, Ahmet,V, (1988): Selimiye Camii ve Külliyesi, c. 36, DİA.

Nutku, Ö. (1972). Dördüncü Mehmet'in Edirne Şenliği-1675, Ankara: TTK

Özcan, A. (1988). Buçuktepe Vak'ası DİA (Vol. 6)

Özcan, A. (2000). Anonim Osmanlı Tarihi: 1099-1166/1688-1704, Ankara: TTK

Özcan, A. (1988). Buçuktepe Vak'ası, , c. 6. DİA.

Özcan, A. (1988). Mahmud I, , c. 27. DİA.

Özcan, A. "Mehmed IV", , c. 28. DİA.

Özcan, A. "Mustafa II", , c. 31. DİA.

Öztuna, Y. (1988), Türk Tarihinden Yapraklar, , İstanbul: Milli Eğitim Bakanlığı Yayınları (MEBY)

Peremeci, O. N. (2010). Edirne Tarihi. İstanbul: Resimli Ay Matbaası.

Sannav, S.C. (2005). Yakındönem Tarihimizde Limni Adası, İstanbu :İstanbul Üniversitesi Sosyal Bilimler Enstitüsü Basılmamış Doktora Tezi,

Sannav, S, C. (2011). Osman İmparatorluğu'na Elektrikli Telgrafın Girişi ve İstanbul'dan Edirne'ye Döşenen İlk Osmanlı Telgraf Hattı, Uluslararası Edirne'nin Fethinin 650. Y11ı Sempozyumu Kitabı, 4-6 Mayıs

Sarınay, Y. (2012). Balkan Savaşları ve Sonuçları, 100. Yılında Balkan Harbi, Balkanlarda Müslüman-Türk Katliamı, Türk Yurdu, Kasım, 2012.

Sertoğlu, M. (2010). Mufassal Osmanlı Tarihi. (M. Cezzar, Ed.) Ankara: TTK.

Turan, S.. (1988). Beyazıd II (Vol. 5). Dia.

Utku, Ö. (1972). Dördüncü Mehmet'in Edirne Şenliği-1675. Ankara: Türk Tarih Kurumu.

Uzunçarşı1l, İ. H. (1988). Osmanlı Tarihi. Ankara: TTK.

Usal, A. (n.d.). Retrieved from Edirne Tarihi: https://docplayer.biz.tr/4524941-Edirne-tarihi-vekulturu-ahmet-usal-edirne-vergi-dairesi-baskanligi.html

Y1lmazer, Ziya (1988) : "Murad IV", c. 31, DİA. 